\title{
Assessing Factors Affecting Moringa Production at North-western Zone of Tigray, Ethiopia
}

\author{
Teklemariam Abadi ${ }^{1}$, Zemeda Desta $^{2} \&$ Hadush Hagos $^{2}$ \\ ${ }^{1}$ Agricultural Extension Researcher, Shire-Maitsebri Agricultural Research Center, P. O. Box81, Shire Indaslassie, \\ Ethiopia \\ ${ }^{2}$ Agricultural Economics Researcher, Mekelle Agricultural Research Center, P. O.B ox492 Mekelle, Ethiopia \\ Corresponding: Teklemariam Abadi, Agricultural Extension Researcher, Shire-Maitsebri Agricultural Research \\ Center, P. O. Box81, Shire Indaslassie, Ethiopia. E-mail: teklish190@mail.com
}

Received: January 3, 2020 Accepted: January 14, 2020 Online Published: March 4, 2020

The research is financed by Tigray Agricultural Research Institute.

\begin{abstract}
Moringa is a highly valued plant that is mostly grown in arid and semi-arid areas which used for food, medication and industrial purposes. This study investigates the factors affecting Moringa plant cultivation among farmers in Northern Ethiopia. A multi-stage sampling procedure was employed to collect data from 54 farmers using questionnaire. Data were analysed using the descriptive statistics. The study identified the socioeconomic characteristics of the sampled respondents. Literate farmers were better in cultivation of Moringa plant than the illiterate one. It also reveals that land size were not the limiting factor for Moringa cultivation in the study area. This study shows that though farmers utilize Moringa, but still there is lack of knowledge on production, utilization, nutritional and economic importance of the plant. Of the total sampled $46.3 \%$ of the respondents used Moringa for human consumption. While compared to the proportion who cultivates Moringa it is relatively low. This low utilization of Moringa in the area attributed due to limited or no awareness on nutritional importance of Moringa and lack of knowledge on preparation of the Moringa utilization. The farmers mentioned that the main constraints that hinder Moringa cultivation is lack of awareness, lack of seedling availability, easily damageable by animals and attacked by termites. Based on the findings; this study recommends that the respective districts, other stakeholders and projects should take responsibilities in creating awareness regarding benefits and utilization process of the plant and offering Moringa seedlings to the society.
\end{abstract}

Keywords: moringa tree, nutritious food, constraints, factors

\section{Introduction}

Moringa species belongs to the family Moringaceae. This family is represented by a single genus Moringa. The genus is represented by 14 species to which Moringa olifera and Moringa stenoptella belongs (Aynalem, 2008; Gebregiorgis e al., 2011). M. stenopetala is native to southern Ethiopia, North Kenya and Eastern Somalia ( Jiru et al., 2006; Gebregiorgis et al., 2011), and M.oleifera is native to India (Jiru et al., 2006; Coppin, 2008). Of the two varieties M. Stenopetala is widely known and grown in most parties of Ethiopia.

Moringa tree grows best in the hot, semi-arid areas and grows in any soil type though prefers well-drained sandy or loam soil, but not grown in water logged soils. It is drought tolerant and grows best at an altitude below $600 \mathrm{~m}$, though it can grow up to $1200 \mathrm{~m}$ (Jahn, 1991). In Ethiopia, Moringa stenopetala grows in elevations between 1,000 and $1,800 \mathrm{~m}$, and it will grow as high as $2000 \mathrm{~m}$ (Alemu and Kelemu, 2013). In general Moringa plants grown easily from seeds or vegetatively propagated tree by cuttings, but Moringa germination from seedlings is more preferable than its vegetative propagation.

The most interesting point in Moringa is all part of the trees except the wood are edible and these edible portions are extremely nutritious. Therefore Moringa can be serves for humans nutrition and animals feed. Moringa contains many essential nutrients, for example, vitamins, minerals, amino acids, beta-carotone, antioxidants and omega 3 and 6 fatty acids (Hsu et al., 2006; Kasolo et al., 2010).

Bosch in 2004 has reported that M. stenopetala as important multi-purpose tree for semiarid climates. The leaves of the Moringa tree are very nutritious. They can be consumed fresh, cooked or dried. Since dried Moringa leaves 
hold their nutrient content, it is possible to convert them into leaf powder. When there is an abundance of leaves, this leaf powder can be made and stored. Moringa leaf powder is an excellent nutritional supplement and can be added to any dish. Moringa leaf powder is consumed as a tea in cafeteria and at home, and at southern part of Ethiopia two spoonful of Moringa powder is added in to dishes, and in the area it is very popular vegetable and grows as backyard tree to make it accessible for daily use (Alemu and Kelemu, 2013).

Moringa tree is locally known as "Shiferaw" in many parts of Ethiopia and the same is called in Tigray northern Ethiopia. Moringa species currently grows in different parts of Ethiopia but mainly growing in southern and western Ethiopia and consumption of Moringa products has noticeably increased in different parts of the country. Though Moringa has not received significant research attention in the country, the area coverage by Moringa is in the increase due to its multiple uses and ability to thrive under harsh environment (Tenaye et al. 2009). Therefore, focusing on perennials for food source is the cheapest and simplest alternative for poor Ethiopian farmers to escape from hanger. Moringa tree is one of the perennials that can be suitable source of food as cabbage, edible oil, water purification, fodder, medicinal value, bee forage and other multiple functions.

Even if in dispersedly Moringa tree is found in many parts of Tigray and the culture of using Moringa products for human consumption is has shown an increment. However, in the study area there is no any empirical study regarding factors affecting on Moringa production. Therefore this study was aimed to assess the factors affecting Moringa production and utilization at north western zone of Tigray.

\section{Research Methodology}

\subsection{Study Areas}

The study was conducted in three districts of north western Tigray, Ethiopia. The districts are namely Tahtay Adyabo, Laelay Adyabo and Tselemti. Tahtay Adyabo Woreda is located at the degree of $14.05-14.89^{\circ} \mathrm{c}$ Northing and $37.34-38.17^{\circ} \mathrm{c}$ Easting. The Woreda has $38-40^{\circ} \mathrm{c}$ of temperature and annual rainfall of $450-550 \mathrm{~mm}$. Agro ecologically $94.13 \%$ of the district is lowland and the remaining $5.87 \%$ is midland. Tselemti Woreda is located in the altitude ranges from 800-2870 meter above sea level, and latitude and longitude of $13^{\circ} 05$ Northing and $38^{\circ}$ 08Easting, respectively. The mean maximum and minimum temperature are $38^{\circ}$ c and $16^{\circ}$ crespectively and the area receives annual rainfall of $758-1100 \mathrm{~mm}$. Agro ecologically $78.35 \%, 19 \%$ and $2.65 \%$ of the Woreda is lowland, midland and highland, respectively. Likewise Laelay Adyabo Woreda is geographically located at $14.08-14.69^{\circ} \mathrm{c}$ Northing and $37.89-38.46^{\circ} \mathrm{c}$ Easting. Agro-ecologically $39.43 \%$ of Woreda is midland and $60.37 \%$ is lowland and the area receives an annual rainfall ranged from $605-1370 \mathrm{~mm}$ (OoARD Woredas, 2016).
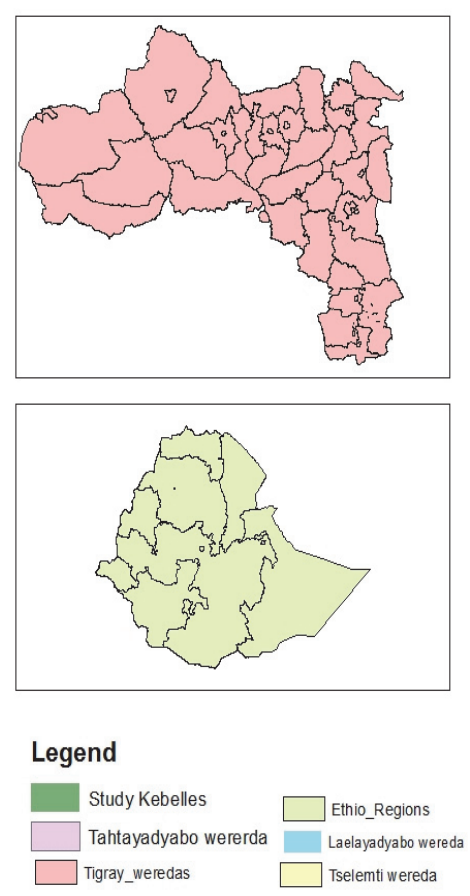
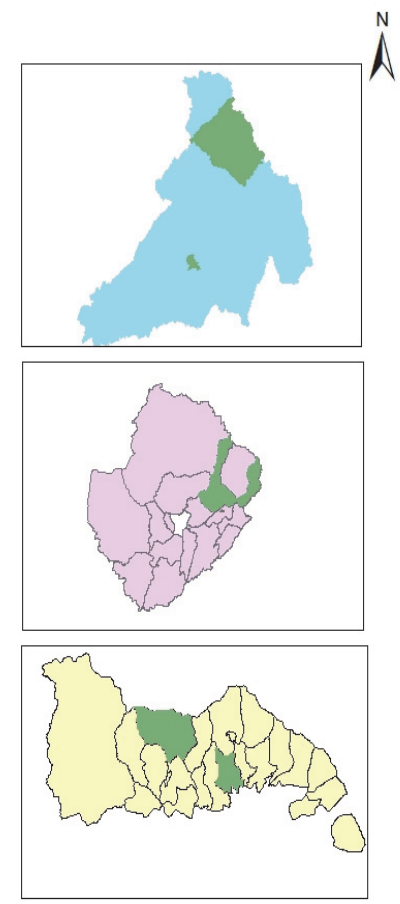

Figure 1. Map of the study areas 


\subsection{Sampling Procedures}

The selected districts were purposively selected based on their potentiality for producing Moringa tree in the zone. A total of six study Kebelles (villages) were randomly selected from the potential Moringa producers Kebelles of the districts. Aditelom and Adiawala Kebelles from Tahtay Adyabo, Adiklte and Ketema Adidaero Kebelles from Laelay Adyabo and Sokotamariam and May-ayni Kebelles from Tselemti Woreda were involved in the study. A total of 54 household head were included in the study by randomly selected based on their sample size.

\subsection{Methods of Data Collection and Analysis}

For the study both primary and secondary data were employed. Primary data were collected using semi-structured questionnaire from sample household from each of the study villages. Secondary data were collected from different relevant sources such as from Office of Agriculture and Rural Development and from different published and unpublished documents. Then the collected quantitative data was analyzed using ddescriptive statistics.

\section{Results and Discussions}

Demographic and Socioeconomic characteristics of the respondents

Moringa trees that were grown on marginal lands of nearby homestead areas were selected. The selected sample farmers for the Moringa tree study are peri-urban residential respondents. The result shows that there were more male farmers $(70.4 \%)$ than their female $(29.6 \%)$ counterparts. $76.3 \%$ of the respondents who own Moringa tree possess an area below one hectare. This indicates cultivating Moringa did not demand large area. $73.7 \%$ the Moringa tree owner ages ranged from 18-75 (Table 1).

Table 1. Demographic and socioeconomic characteristics of the respondents $(n=54)$

\begin{tabular}{|c|c|c|c|c|c|}
\hline \multicolumn{2}{|c|}{ Variables } & \multicolumn{2}{|c|}{ Total participants } & \multicolumn{2}{|c|}{ Moringa tree owners } \\
\hline & & Frequency & Percentage & Frequency & Percentage \\
\hline \multirow[t]{2}{*}{ Sex } & Male & 38 & 70.4 & 24 & 63.2 \\
\hline & Female & 16 & 29.6 & 14 & 36.8 \\
\hline \multirow[t]{4}{*}{ Age (years) } & $18-30$ & 5 & 9.3 & 3 & 7.9 \\
\hline & $31-45$ & 18 & 33.3 & 15 & 39.5 \\
\hline & $46-60$ & 19 & 35.2 & 10 & 26.3 \\
\hline & $61-75$ & 12 & 22.2 & 10 & 26.3 \\
\hline \multirow{4}{*}{$\begin{array}{l}\text { Education } \\
\text { status }\end{array}$} & Illiterate & 18 & 33.3 & 9 & 23.7 \\
\hline & Read and write & 15 & 27.8 & 10 & 26.3 \\
\hline & Elementary school & 13 & 24.1 & 13 & 34.2 \\
\hline & $\begin{array}{c}\text { Secondary school and } \\
\text { above }\end{array}$ & 8 & 14.8 & 6 & 15.8 \\
\hline \multirow[t]{5}{*}{ Landholding } & Landless & 12 & 22.2 & 9 & 23.7 \\
\hline & $0.1-0.5 \mathrm{ha}$ & 15 & 27.8 & 11 & 28.9 \\
\hline & $0.51-1$ ha & 13 & 24.1 & 9 & 23.7 \\
\hline & $1.1-1.5 \mathrm{ha}$ & 12 & 22.2 & 7 & 18.4 \\
\hline & $>1.51 \mathrm{ha}$ & 2 & 3.7 & 2 & 5.3 \\
\hline \multirow[t]{3}{*}{ Marital status } & Single & 5 & 9.3 & 2 & 5.3 \\
\hline & Married & 38 & 70.4 & 27 & 71.1 \\
\hline & Divorced/Widowed & 11 & 20.3 & 9 & 23.7 \\
\hline \multirow[t]{5}{*}{ Occupation } & Farming & 35 & 64.8 & 22 & 57.9 \\
\hline & Trading & 5 & 9.3 & 3 & 7.9 \\
\hline & Civil servant & 6 & 11.1 & 5 & 13.1 \\
\hline & Daily labor & 2 & 3.7 & 2 & 5.3 \\
\hline & Trading and farming & 6 & 11.1 & 6 & 15.8 \\
\hline
\end{tabular}

There was no significant difference in household characteristics in sex, age, marital status, occupation and farm size. But education status indicated a significant difference between the Moringa tree grower and non-growers. As the farmers became more educated he/she has the probability of growing Moringa tree in the area (Table 2). 
Table 2. Chi-square Tests of sampled households characteristics in the sampled districts

\begin{tabular}{lll}
\hline Household characteristics & Chi-square value & P-value \\
\hline Sex & 0.711 & 0.399 \\
Age & 5.543 & 0.136 \\
Marital status & 3.299 & 0.348 \\
Education status & 9.637 & $0.086^{*}$ \\
Occupation & 5.057 & 0.281 \\
Farm size & 1.871 & 0.760 \\
\hline
\end{tabular}

Significance level: $*=\mathrm{P}<0.1$ significant

Of the sampled farmers, the Moringa consumer used Moringa as food (27.8\%), for tea (9.2\%), for food and tea (9.2\%). Of the Moringa consumer respondents $5(20 \%)$ are not the owners of Moringa tree but utilizing Moringa leaf by borrowing or by taking from those who own Moringa tree (Table 3). However from the total Moringa tree owners of the sampled farmers 18 (47.4\%) were not utilized any apart of the Moringa tree except they used it for shed and fire woods (table 3). From the sampled respondents, all of the Moringa consumers (25) were used the leaf part of the tree. They used by picking the growing tips and young leaves, by cooking the fresh picked leave in to water for tea purpose or by drying it and used it as powder to add to different sauces or boiled water for tea. Studies from other countries also indicate that the many peoples have used Moringa leaves for human consumption due to the leaves have immense nutritional value such as vitamins, minerals and amino acids (Anwar et al., 2007).

Table 3. Purpose of Moringa tree used by the sampled respondents in the area

\begin{tabular}{llllllll}
\hline & \multirow{2}{*}{$\begin{array}{l}\text { Moringa } \\
\text { purpose }\end{array}$} & \multicolumn{2}{c}{ Moringa owners } & \multicolumn{2}{c}{ Non owners } & \multicolumn{2}{c}{ Total } \\
\cline { 2 - 7 } $\mathbf{1}$ & Frequency & Percentage & Frequency & Percentage & Frequency & Percentage \\
$\mathbf{2}$ & Tea & 13 & 34.2 & 2 & 12.5 & 15 & 27.8 \\
$\mathbf{3}$ & Tea and food & 4 & 7.9 & 2 & 12.5 & 5 & 9.2 \\
$\mathbf{4}$ & Shed & 4 & 10.5 & 1 & 6.25 & 5 & 9.2 \\
$\mathbf{5}$ & Fire wood & 2 & 10.5 & - & - & 4 & 7.4 \\
$\mathbf{6}$ & Not used so far & 12 & 5.3 & - & - & 2 & 3.7 \\
& Total & 38 & 31.6 & 11 & 68.75 & 23 & 42.6 \\
\hline
\end{tabular}

As seen the result from Table 4, the main constraints to use Moringa as human consumption in the area is due to lack of awareness its health and nutritional benefits, cultural drawbacks of the plant and absence of the plant with percentages of $74.07 \%, 16.6 \%$ and 9.29 respectively(Table4). The sampled farmers respond that as few farmers believe that consuming Moringa leaves can decrease the blood of the body and cause to anaemia. However the finding of Kasolo et al., 2010 shows Moringa leaves have many benefits to human such as treating malnutrition, diabetes mellitus, gastritis, asthma, heart burn, bone setting, skin disease and anti-hypertensive but not mentioned any drawbacks of the plant.

Table 4. The challenges not to utilize Moringa in the study area

\begin{tabular}{lll}
\hline SN & \multicolumn{1}{c}{ Causes } & Percent (\%) \\
\hline $\mathbf{1}$ & Lack of awareness & 74.07 \\
$\mathbf{2}$ & Cultural draw backs & 16.6 \\
$\mathbf{3}$ & Absence of Moringa tree & 9.29 \\
\hline
\end{tabular}

The major constraints for Moringa production in the study area are associated to lack of awareness on the tree, lack of planting material (seedling) and damageable by animals and by termites (Table 5). These could hinder the Moringa production in the study area. Inconsistent to this study, Opeyemi et al. (2013) has reported that creating the benefits of Moringa on the society is one among the driving force for adopting and producing Moringa tree. The study shows that peoples in the area were less aware regarding management and utilizing of the Moringa tree. Animals like donkey are highly interested to eat the bark of the stem and expose it to be dried the Moringa tree. 
Similar to this study the report of Moshibudi et al. (2017) also reveals that farmers are getting challenges like free roaming animals, termites and lack of training for Moringa production.

Table 5. The major constraints in Moringa production

\begin{tabular}{lll}
\hline SN & Constraints & Rank \\
\hline $\mathbf{1}$ & Lack of awareness on the nutritional and economic benefits of Moringa production $(56.5 \%)$ & $1^{\text {st }}$ \\
$\mathbf{2}$ & Damaged by animals $(15 \%)$ & $3^{\text {rd }}$ \\
$\mathbf{3}$ & Attacked by termite $(9.2 \%)$ & $4^{\text {th }}$ \\
$\mathbf{4}$ & Lack of Moringa seedling $(19.3 \%)$ & $2^{\text {nd }}$ \\
\hline
\end{tabular}

\section{Conclusions and Recommendations}

Moringa is gaining prominence in the study area. In the study area farmers utilize Moringa its leaf part mostly in powder form. But there is a dearth of information and knowledge on its production, utilization and economic importance. According to this finding only $46.3 \%$ of the respondents used Moringa for human consumption. But when we compared this to the proportion who cultivates Moringa, relatively lower $(70.4 \%)$ has the plant on their farms but did not use it for their consumption. Low utilization of Moringa in the study area could attribute due to limited or no awareness nutritional importance of the plant. As the analysis of the result indicates there are constraints such as lack of awareness, lack of seedling availability, easily damageable by animals and attacked by termites in Moringa production. Based on these findings; this study recommends that the respective districts, other stakeholders and projects should take responsibilities in creation awareness on benefits and utilization process of the plant and in distributing the Moringa tree seedlings in a continuous way. Guide line manual on Moringa production, its importance regarding nutritional and its utilization process which prepared in a local languages should promoted to the farmers by taking the lead the research institutions.

\section{Acknowledgement}

The authors would like to acknowledge Tigray Agricultural Research Institute, Shire-Maitsebri Agricultural Research Center for the research grant. Special thanks also go to agricultural experts and respondent farmers and experts of the districts for their kind cooperation in conducting the study.

\section{References}

Alemu, D., \& Kelemu, K. (2013). Commercialization of Moringa Production in Ethiopia: Establishing model value chains for Moringa in Ethiopia. Conference: Commercialization of Moringa production in Ethiopia: Experience and success stories, EIAR At: Ethiopian Institute of Agricultural Research, Addis Ababa. Retrieved from http://publication.eiar.gov.et

Anwar, F., \& Rashid, U. (2007). Physico-chemical characteristics of moringa Oleifera seeds and seed oil from a wild provenance of Pakistan. Journal. Bot., 39(5), 1443-1453.

Aynalem, A. E. (2008). Moringa stenopetala seed oil as a potential feedstock for Biodiesel production in Ethiopia. Jour. Env't. Sc.

Bosch, C. H. (2004). Moringa oleifera Lam. In Grubben, G. J. H., \& Denton, O. A. (Eds.), PROTA (Plant Resources of Tropical Africa/Ressources végétales de l'Afrique tropicale), Wageningen, Netherlands. Retrieved from http://www.prota4u.org/search.asp.

Coppin, J. (2008). A Study of the Nutritional and Medicinal Values of Moringa oleifera Leaves from Sub-Saharan Africa: Ghana, Rwanda, Senegal and Zambia (Doctoral dissertation, Rutgers University-Graduate SchoolNew Brunswick).

Gebregiorgis, F., Negesse, T., \& Nurfeta, A. (2011). Feed intake and utilization in sheep fed graded levels of dried Moringa (Moringa stenopetala) leaf as a supplement to Rhodes grass hay. Tropical Animal Health and Production, 44(3), 511-7. https://doi.org/10.1007/s11250-011-9927-9

Hsu, R., Midcap, S., \& Arbainsyah, D. W. L. (2006). Moringa oleifera: Medicinal and Socio-Economical Uses. Internationa Course on Economic Botany, National Herbarium Leiden, the Netherlands. Retrieved from https://docplayer.net/53749363-Moringa-oleifera-medicinal-and-socio-economic-uses.html

Jahn, S. A. A. (1991). The traditional domestication of a multipurpose tree Moringa stenopetala Bak.f. Cuf. in the Ethiopian rift valley. Ambio, 20(6), 244-247. Retrieved from https://www.jstor.org/stable/4313833.

Jiru, D., Sonder, K., Alemayehu, L., Mekonen, Y., \& Anjulo, A. (2006). Leaf yield and Nutritive value of Moringa 
stenopetala and Moringa oleifera Accessions: its potential role in food security in constrained dry farming agroforestry systems. Proceedings of the Moringa and other highly nutritious plant resources: Strategies, standards and markets for a better impact on nutrition in Africa. Accra, Ghana, November 16-18, 2006

Kasolo, J. N., Bimenya, G. S., Ojok, L., Ochieng, J., \& Okeng, O. W. J. (2010). Phytochemicals and uses of Moringa oleifera leaves in Ugandan rural communities. Journal of Medicinal Plants Research, 4(9), 753-757. Retrieved from http://www. academicjournals.org/JMPR

Moshibudi, P. M., Kingsley, K. A., Irvine, K., Ramasela, C. M., \& Richard, S. Ch. (2017). Production and Utilization of Moringa by farmers in Limpopo province, Southe Africa. Int. J. Agric. Res., 12, 160-171. https://doi.org/10.3923/ijar.2017.160.171

Office of Agriculture and Rural Developments of the hosted Woredas. (2016). Unpublished annual report.

Opeyemi, A. E., Jubril, A. O., Segun, F. B., Abdulazeez, M. L., Abraham, F., John, I. O., \& Ayokunle, A. T. (2013). An Assessment of the Determinants of Moringa Cultivation among Small-Scale Famers in Kwara State, Nigeria. 2013. Food Science and Quality Management, 11, 2013. Retrieved from www.iiste.org

Tenaye, A., Geta, E., \& Hebana, E. (2009). A MULTIPURPOSE CABBAGE TREE (MORINGA STENOPETALA): PRODUCTION, UTILIZATION AND MARKETING IN SNNPR, ETHIOPIA. Acta Hortic., 806, 115-120. https://doi.org/10.17660/ActaHortic.2009.806.12

\section{Copyrights}

Copyright for this article is retained by the author(s), with first publication rights granted to the journal.

This is an open-access article distributed under the terms and conditions of the Creative Commons Attribution license (http://creativecommons.org/licenses/by/4.0/). 